\title{
Criteria and Indicators for Evaluating the Efficiency of the State Regional Youth Policy
}

\author{
Mikhail B. Dvinskiy and Elena N. Pochekutova* \\ Siberian Federal University \\ 79 Svobodny, Krasnoyarsk, 660041, Russia
}

Received 26.07.2015, received in revised form 21.08.2015, accepted 30.09.2015

\begin{abstract}
The article discusses the principles of developing criteria and indicators to evaluate the efficiency of the state youth policy at the level of the region of the Russian Federation. Groups of quality and quantity criteria for monitoring the integration of institutions in the youth policy are considered. It is recommended to divide quantity criteria into two groups: intensive and extensive. The article proposes introduction of additional mechanisms in the region of the Russian Federation to ensure maximum support and adaptation of the youth policy.
\end{abstract}

Keywords: state youth policy, institutions and entities of the youth policy, monitoring of the state youth policy, efficiency criteria, efficiency indicators, mechanisms to ensure support and adaptation of the youth policy.

The article was prepared within the framework of the research project under the municipal contract No. 53-21 dated August 13, 2015: "Development of Projects of the Strategy of Socio-economic Development of the city of Krasnoyarsk up to 2030 and the Action Plan for its Implementation".

DOI: 10.17516/1997-1370-2015-8-11-2348-2355.

Research area: economics.

\section{Introduction}

With regard to the present stage of the state youth policy development, the legal basis of the state youth policy constitutionally provides guarantees of the rights and freedoms of youth, creating conditions for the development of personalities, as well as protection of the rights and interests of young people. The State Youth Policy Strategy for the period until 2016 approved by the Decree No. 1760-r of the Government of the Russian Federation as of December 18, 2006 (Rasporiazhenie Pravitel'stva Rossiiskoi Federatsii ot 18 dekabria 2006 g. No. 1760-r), determines the interests and needs of different groups of young people, the involvement of young people in the development and implementation of the priority directions of the state youth policy as the implementation of the principles. Application of the programme-target method of management was developed in the State Youth Policy approved by the Decree 2403-p of the Russian Federation dated November 29, 2014 (Decree No. 2403-r of the Government of the Russian Federation dated November 29, 2014).

The aim of the state youth policy is to create conditions for successful socialization and

(C) Siberian Federal University. All rights reserved

* Corresponding author E-mail address: potschekutova@mail.ru 
efficient personal fulfillment of young people, development of the potential of the youth and its use for the benefit of the innovative development of the country.

The practice of recent decades proves that in a rapidly changing world, those countries will have strategic benefits that can effectively develop and efficiently use the innovation potential of development, the main carrier of which is the youth.

The state youth policy should be considered as an independent activity of the state generating necessary social conditions for the innovative development of the country, which is fulfilled on the basis of active cooperation with the civil society institutions, associations and youth organizations.

\section{Institutional participants of the state youth policy}

The state youth policy is the activity of the state aimed at creation of legal, economic and organizational conditions and guarantees for personal fulfillment and development of youth associations, movements and initiatives. The state youth policy expresses the strategic policy of the state in relation to the younger generation to ensure the socio-economic, political and cultural development of Russia, to raise patriotism and respect for the history and culture of the country and other nations among young citizens of the country, to focus them on the observance of human rights.

The state youth policy is carried out in relation to:

- youth as a socio-demographic group determined on the basis of age peculiarities, social status and characterized by specific interests and values. This group includes those aged from 14 to 30 years, and in some cases determined by the certain regulations of the Russian Federation and the subjects of the Russian Federation, those aged to 35 or more years with permanent residence in the Russian Federation or living abroad (citizens of the Russian Federation and compatriots) (Decree No. 2403-r of the Government of the Russian Federation dated November 29, 2014);

- young family in the first registered marriage, in which the age of each of the spouses or one parent in an incomplete family does not exceed 30 years (for participants of housing programmes to support young families, the age of participants increases to 35 years);

- a young specialist, a citizen of the Russian Federation under the age of 30 (for participants of housing programmes to support young specialists up to 35 years old) with secondary vocational or higher education recruited under the employment contract in accordance with the level of vocational training and qualification;

- a young scientist, a staff member of an educational or scientific organization, having a Candidate of Science degree under the age of 35 or a Doctor of Science degree under the age of 40 (for participants of the programmes helping to solve housing problems of employees up to 45 years old) or a graduate student, a researcher or a teacher of an educational institution of higher education without a degree under the age of 30 .

The state youth policy is carried out by:

- state authorities and their officials;

- youth unions and their associations;

- young citizens.

The state youth policy of the Russian Federation is based on the following principles: 
- responsibility of the state for the observance of the legitimate interests of young people;

- responsibility of young people for the implementation of their constitutional rights and responsibilities in the spheres of public life;

- recognition of young people as an equal partner in the development and implementation of the state youth policy;

- priority of the state support of disadvantaged young people;

- basic services for the spiritual, cultural, social, physical and mental development of young people provided by the state, as well as possibilities for life choices, education, start of a career, founding a family;

- support of the activity of youth public unions and organizations;

- development of the public-private partnership and interaction with social institutes;

- increase of the efficiency of using information resources and infrastructure for the support of the state youth policy;

- strengthening of the legal regulation mechanisms and the integrity of the state youth policy at the federal, regional and municipal levels;

- interaction of various agencies in implementation of the strategy and programmes related to the state youth policy (Decree No. 2403-r of the Government of the Russian Federation dated November 29, 2014).

The state youth policy is a system of state priorities and measures aimed at creating conditions and opportunities for the successful socialization and effective personal development of young people to evolve their potential in
Russia's interests and, consequently, to foster the socio-economic and cultural development of the country, ensuring its competitiveness and strengthening national security.

The state youth policy is formed and implemented by state and local authorities with the participation of youth and children organizations, non-governmental organizations and other legal entities and individuals.

\section{Methods and approaches}

Due to the rapid aging of the population and unfavourable demographic trends, today's 10-25-year-old citizens will become the main labour resources in Russia, their labour activity is the source of funds for the welfare of children, the disabled and senior citizens.

The state youth policy as a sphere of public administration assumes its own system of indicators of efficiency and effectiveness of the state support on both the federal level and the level of the subject of the Russian Federation. There is no developed monitoring system for evaluating the effectiveness and efficiency of the activities of state and municipal authorities in the implementation of the state youth policy in Russia.

The following types of criteria are most frequently used in the system analysis:

1. Criteria of the "cost - efficiency" type, which are based on the comparison of value estimation of the resources expenditure with the results of a particular course of action, and involving not only the measurement of technical and economic parameters, but also the assessment of social consequences of a particular course of action.

2. "Eliminating" criteria, which determine the range of desired values of the system's most important parameters and exclude all of the options when at least one parameter does not fall within the required range limiting the criterion. 
3. "Scaling" criteria representing artificially constructed "relative importance coefficients" that are assigned to various important characteristics of the system being analyzed by experts and allow to calculate the "indexes" of the relative importance of solutions.

The criteria should meet the following requirements:

- representativeness, i.e. consider the main parameters of the system's action, its features, properties, purposes;

- response to the values of the system's parameters (indicators) being studied;

- simplicity of determining and calculating their values using the given parameters of the system.

Typically, the best solution in the system analysis is considered to be the one that ensures the achievement of the goal with the minimum expenditure of resources. Another option is also possible: the best solution is the one that provides the maximum effect at the fixed expenditure of resources. In the sphere of the state youth policy, the use of only one criterion of efficiency is unacceptable due to the specificity of diversified and institutional collaboration.

The materials of the state youth policy monitoring of November 16, 2009, provided by the Federal Agency for Youth Affairs determine the problem of developing the evaluation criteria of the efficiency of the youth policy and the inappropriateness of a standard approach (from the point of view of economic efficiency) to the development of the system of indicators. One of the important aspects of the state youth policy monitoring is the evaluation of the policy's efficiency at every level of government: federal, regional and municipal (Resolution No. 409 of the Government of the Russian Federation dated May 29, 2008).

Basing on the objectives of the state youth policy determined in the Strategy, we can conclude that young people are currently not enough involved, not enough informed, not enough supported by the state. They are the carriers of poorly developed legal, cultural and moral values. Thus, the current indicators of the youth's state can be quite arbitrarily taken as a point of no return. Herewith, the idea that the deterioration of the existing indicators is beyond the scope of discussion, i.e. unacceptable, is stated quite strictly.

There may be internal and external indicators and criteria to evaluate the activities of the Federal Agency for Youth Affairs, internal in relation to the subject of control, external in relation to the object, while the quality, consistency and coordination of the activities of the object under control inevitably affects the external criteria and indicators.

The effectiveness of the project the activities of the Federal Agency for Youth Affairs can be quantitatively evaluated by comparative analysis of trends in changes of certain characteristics. The qualitative assessment of the effectiveness of the work may be carried out by the following parameters: coordination of the activities of substructures; formed and continuously growing database of the different categories of young people (innovators, difficult teenagers, the unemployed, talented); the existing legal framework; a project approach to the programmes and projects with specified timing, results and resources; quantity and quality of developed, formed and fulfilled projects, programmes and activities; coverage of the target audience; quality of training in the field of youth policy.

The effective work of the executive body may be one of the criteria for evaluating the effectiveness of the state youth policy in general. There is no integrated performance evaluation that takes into account the variety of technologies and support measure, and the use of integrated assessment is not assumed. 
The second criterion for assessing the effectiveness of the state youth policy can be the level of technological (fast) and effective (qualitative, meeting the necessary conditions for project activities) interaction between all subjects involved in efforts to create the necessary conditions for successful socialization of young people.

The third criterion for assessing the effectiveness of the state youth policy is the complexity of developed systems, that is, how competently and promptly do they consider the interests of the participants of the process and the conditions in which this system works. During the evaluation of the effectiveness, a set of indicators of various aspects, such as financial, time, methodological and organizational, should be considered.

\section{Methodological basis \\ for the development of criteria and indicators to evaluate the efficiency \\ of the state regional youth policy}

The analysis of the main characteristics of institutions of the regional youth policy of the Krasnoyarsk Territory (Krai) allowed to identify some of the main issues of its implementation. The practice of the Krasnoyarsk Territory (Krai) in developing and implementing the youth policy, is a unique material for defining effective mechanisms to improve not only the administrative processes, but the main activities of the existing system of the youth policy in the Krasnoyarsk Territory (Krai).

In order to ensure a comprehensive, well thought-out and manageable integration of institutions in the youth policy, some indicators identified through the analysis of the troubled areas in the region's youth policy are proposed. These indicators will help to assess the efficiency of activities of the regional youth policy institutions based on various mechanisms. These criteria were partially introduced during the development of the state programme of the Krasnoyarsk Territory (Krai) "Youth of the Krasnoyarsk Territory (Krai) in the $21^{\text {st }}$ century" (Resolution No. 519-p of the Government of the Krasnoyarsk Territory (Krai) dated September 30, 2013).

The proposed criteria and indicators can be nominally divided into two groups: quality and quantity.

\section{Quality criteria:}

- the rate of changes in the regional youth policy balance (the improvement of the regional youth policy in this case would be determined by the presence of structures representing the interests of the public and the youth, youth involvement in the development and implementation of the regional youth policy on their own, etc.);

- development of the least subjective indicators to assess the development of the regional youth policy (carried out through the development and legal binding standards to assess the potential development of the regional youth policy, the objectivity of the indicators themselves is evaluated by means of three categories: achievement of the objective, quality use of different resources, the amount of young people whose problems in the designated areas have been resolved);

- achievement of intermediate objectives in the priority areas of the youth policy (key targets, in fact, are the interim results of the work. In the course of the development of a certain trend in the framework of the regional youth policy it is proposed to determine short-term objectives, the time for achievement of which should not exceed six months);

- target use of the material and social resources (this indicator reflects the 
effective integration of the regional youth policy pursued by various institutions in the social development system, while this indicator is a distinctive feature of the organization of the youth policy implementation in general);

- forecasting the most accurate results of the implementation of measures developed and implemented within the framework of the complex regional youth policy (similar evaluation mechanism exists as a part of social planning as a separate activity);

- the possibility of more accurate shortand medium-term planning (comparison of the developed plan to achieve welldefined, quantity and quality indicators and the actual outcome of the objectives determined by the youth policy institute);

- introduction and activation of new subjects in the system of the regional youth policy (the institute of social work that has been actively expanding lately can become one of such subjects at the present stage);

- no duplication of functions by different institutions of the regional youth policy.

These indicators developed by correlating the systems of criteria for the evaluation of other institutions of the state, society and youth policy existing independently, has proven to be effective. Nevertheless, modern practice of the youth policy institutions at all levels of development and implementation of the regional youth policy in Krasnoyarsk and the Krasnoyarsk Territory (Krai) shows that many of these indicators cannot be applied to the intermediate and final results of the use of this mechanism in the regional youth policy.

Quantity criteria can be also subdivided into two groups: intensive and extensive.

\section{Extensive quantity criteria:}

- the amount of young people involved in the development and implementation of the regional youth policy during a certain period (one year);

- the amount of project applications (other types of activities) submitted by young people within all existing areas (during the reporting period, one year);

- the amount of initiatives of young people that have been approved by the expert committee for implementation;

- the amount of initiatives of the youth policy institutes approved for implementation (during the reporting period, half a year);

- expansion of the geography of the youth policy institutes activities to achieve major social objectives (increase of the amount of territories).

\section{Intensive quantity criteria:}

- the percentage of the three groups of young people involved by the time of their activities in the system of the regional youth policy (one-time, less than one year (short-term), from one year to 3-5 years (medium-term), more than six years (long-term);

- the degree of active participation (the number of submitted initiatives and decisions by a young person or an initiative group during the reporting period, one year);

- the degree of participation of institutions (the number of submitted initiatives and decisions by one or more youth policy institutions during the reporting period, one year);

- the degree of polarization of youth participation in the regional youth policy (the number of priority areas of the regional youth policy involving a young person or an initiative group during the reporting period, three to five years); 
- the ratio of the number of youth initiatives submitted for consideration and implemented.

\section{Conclusions}

Certainly, a set of criteria and indicators to evaluate the effectiveness of activities of the youth policy institutions in the region used in the practice of the state programmes development, promotes the development of the regional youth policy. The Krasnoyarsk Territory (Krai) has quite extensive experience of the use of social engineering and other mechanisms for the implementation of the youth policy in the region.

It is possible to improve this practice through the introduction of criteria and indicators to assess the level of efficiency of activities of the youth policy institutions as described above. This will accelerate the transition from quantitative to qualitative changes.
The experience of the institutes in the development and implementation the youth policy in the city of Krasnoyarsk and the Krasnoyarsk Territory (Krai) shows that the problem of the insufficient level of effectiveness of the implementation mechanisms in the framework of the regional youth policy lies in the lack of a systematic approach to its organization.

It is primarily characterized by specific features of the activities on the development and implementation of the youth policy, the lack of sufficient experience in the application of the mechanisms of social and design work and actual problems arising in the course of integration of the youth policy, new instruments and mechanisms used by the youth policy institutions, and the lack of adequate attention to the context: the level and dynamics of the development of the society as the subject of the Russian Federation.

\section{References}

Ob utverzhdenii gosudarstvennoi programmy Krasnoiarskogo kraia "Molodezh' Krasnoiarskogo kraia vXXI veke" [On the approval of the state programme of the Krasnoyarsk Territory (Krai) "Youth of the Krasnoyarsk Territory (Krai) in the $21^{\text {st }}$ century"](Postanovlenie Pravitel'stva Krasnoiarskogo kraia ot 30.09.2013 g. No. 519-p, v red. Postanovlenii Pravitel'stva Krasnoiarskogo kraia ot 27.08.2014 No. 381-p, ot 30.09.2014 No. 429-p, ot 12.11.2014 No. 522-p, ot 12.08.2015 No. 428-p) [Resolution No. 519-p of the Government of the Krasnoyarsk Territory (Krai) dated September 30, 2013, in the edited version of the Resolution No. 381-p of the Government of the Krasnoyarsk Territory (Krai) dated August 27, 2014, No. 429-p dated September 30, 2014, No. 522-p dated November 12, 2014, No. 428-p dated August 12, 2015]. Available at: http://consultant.ru (accessed on September 24, 2015).

Ob utverzhdenii osnov gosudarstvennoi molodezhnoi politiki Rossiiskoi Federacii na period do 2025 goda [On the approval of the state youth police of the Russian Federation for the period until 2025].(Rasporiazhenie Pravitel'stva Rossiiskoi Federatsii ot 29 noiabria 2014 g. No. 2403-r) [Decree No.2403-r of the Government of the Russian Federation dated November 29, 2014). Available at: http:// consultant.ru (accessed on September 24, 2015).

Polozhenie o Federal'nom agenstve po delam molodezhi [Statement on the Federal Agency on the Youth Affairs]. (Postanovlenie Pravitel'stva Rossiiskoi Federatsii ot 29 maia 2008 g. No. 409) [Resolution No. 409 of the Government of the Russian Federation dated May 29, 2008] Available at: http://consultant.ru (accessed on September 24, 2015).

Strategiia gosudarstvennoi molodezhnoi politiki Rossiiskoi Federatsii [Strategy of the state youth policy of the Russian Federation]. (Rasporiazhenie Pravitel'stva Rossiiskoi Federatsii ot 18 dekabria 
2006 g. No. 1760-r) [Decree No. 1760-r of the Government of the Russian Federation dated December 18, 2006]. Available at: http://consultant.ru (accessed on September 24, 2015).

\section{Критерии и индикаторы оценки эффективности государственной региональной молодежной политики}

М.Б. Двинский, Е.Н. Почекутова Сибирский федеральный университет Россия, 660041, Красноярск, пр. Свободный, 79

В статье рассматриваются принщипы разработки критериев и индикаторов для оценки эффективности государственной молодежной политики на уровне субъекта Российской Федерачии. Обосновываются группы качественных и количественных критериев для осуществления мониторинга интеграции институтов в молодежную политику. Количественные критерии рекомендуется разделить на две группы: интенсивные и экстенсивные. Предложено введение на территории субъекта Федерации дополнительных механизмов, обеспечивающих максимальную поддержку и адаптачию молодежной политики.

Ключевые слова: государственная молодежная политика, институты и субъекты государственной молодежной политики, мониторинг эффективности государственной молодежной политики, критерии эффективности, индикаторы эффективности, механизмы обеспечения поддержки и адаптации молодежной политики.

Статья подготовлена в рамках научно-исследовательской работы по Муниципальному контракту № 53-21 от 13 августа 2015 года: «Разработка проектов Стратегии сочиальноэкономического развития города Красноярска до 2030 года и плана мероприятий по ее реализациии».

Научная специальность: 08.00.00 - экономические науки. 